\title{
A New Approach to Mamluk Official Processions within Cairo and its Environs from Tour Guiding Perspective An Analytic Study
}

\author{
Ahmad Awaad Hussein \\ Tour Guiding Department \\ High Institute of Tourism, Hotel Management and Monuments Restoration, Alexandria
}

\begin{abstract}
This study does primarily focus on analyzing the official state Cairene processions in Mamlūk Egypt from tour guiding perspective. Those official processions are classified into multiple categories, based on their nature and objective, such as the sultanic i.e. throne ascension, military, social, religious, sports, and funerary parades. The analytic scholarship of those corteges played an axial role in revealing some useful information in connection with underscoring of many substantial political, economic, socio-religious, and architectural aspects in Mamlūk Egypt. Additionally, the study aimed at materializing many symbolic meanings that were indirectly delivered to the populace via the organization of those processions. Revelation of sueh information, whether tangible or symbolic, could be used by professional tour guides upon addressing the philosophical dimensions of any visited Mamlūk archaeological site.

Keywords: Processions-Maydān- Urbanization-Processional Routes-Cairene.
\end{abstract}

\section{Introduction:}

"Good bye England's rose... it seems to me you lived your life like a candle in the wind... never fading with the sunset... when the rain set in." these touchy words were sung by Elton John on 6 September 1997 in favor of Diana, Princess of Wales, during her funerary ceremony in London. Two thousand people attended the ceremony in Westminster Abbey while the British television audience peaked at 32 million, one of the United Kingdom highest viewing figures ever, in addition to millions of other viewers around the world. It could be understood from this brief introduction that any official procession, regardless its nature, is organized by the government in terms of propagandizing a specific notion, concept or event in front of the populace to attain a certain goal, most likely, of political nature.

Despite the fact that the prime subject of this paper is the processions in medieval Egypt, it is important to know that the concept of processioning itself in Egypt dates back to the earliest periods of its long history, namely, the ancient Egyptian civilization. Narmer palette in the Egyptian museum demonstrates the procession notion. This palette dates back to the proto dynastic period, c. 3000 B.C. It commemorates the victories of king Narmer, unifier of Upper and Lower Egypt. On one side, the king is depicted marching in a triumphal procession towards the temple of Horus, while inspecting the bound and beheaded corpses of enemies lying in two rows in front of him (fig.1). ${ }^{1}$ Surprisingly, the concept of procession was a core turning point in the Greco-Roman history of Egypt. The fear of being exposed as a captive queen in Octavius Caesar's victory parade in Rome compelled Cleopatra the seventh to commit suicide in 31 B.C. after the murder of Mark Anthony. Her death marked the end of the Ptolemaic dynasty and the beginning of the Roman period. ${ }^{2}$

\section{Objective:}

Throughout the history of Islamic Egypt, the concept of official procession had been fully crystallized during the Mamlūk dynasty, (1250-1517). In this context, it is believed that analyzing the outlines of Mamlūk official processions in medieval Cairo could reveal some valuable information about the architectural, political, religious, social and economic aspects and traditions that prevailed in many phases throughout the lifespan of Mamlūk Egypt. Such information is intended to be used by professional tour guides in terms of better demonstration of the philosophical backgrounds of the visited Mamlūk historic or archaeological site.

Accordingly, this study aims at analyzing the philosophical approach of the Mamlūk Sultans to various types of official procession in terms of materializing the symbolic meanings which lie within different activities, traditions and rituals of those processions.

Undoubtedly, most of the Mamlūk Sultans were eager at consecrating every possible facility to consolidate their sovereignty and political authority in Egypt through demonstrating their military power. The main motif behind that trend was to politically recruit the Egyptians who were still looking down, at the Mamlūks as aliens and military slaves who illegally ascended the throne of the sultanate through usurping the ruler ship from their former masters, the Ayyubids.

Al-Mawkib al-Sulțāni or the sultanic procession was, for most of the Mamlūk sultans, the one sociopolitical effective device in terms of consolidating their political authority on both basis; officially and public. That sultanic procession, which was prominently organized to celebrate the new Sultan's ascension to the throne, ${ }^{4}$ had always featured two phases. The first phase took place at the citadel, the official residence of the Sultan and the government house of the sultanate, where the 'Abbasid Caliph, the four qâdis and the major Mamlūk Amīrs met to officially acknowledge the new Sultan. ${ }^{5}$ After receiving the oath of allegiance from selective attendees, the new Sultan was offered, by the Caliph, the official sultanic costume, namely, a black khil'a, a turban and a sword. Afterwards, the Mamlūk Amīrs stepped forward towards the Sultan to kiss his hand and the floor before him in respect of showing their loyalty. ${ }^{6}$ At that point, the sultanic procession departed the citadel to exhibit al-darb al-sultanī which was a prime Cairene processional artery. Markedly, both sides of aldarb al-sultanī were packed by with thousands of populace of different social strata, who came from all over Egypt to witness such an important occasion. Accordingly, most of the Mamlūk Sultans exploited the sultanic procession in affirming their political role and royal status in the minds of the public rather than being always remembered as military slaves. In this context, the Mamlūk Sultans had always been keen on being accompanied by the Caliph in connection with adding a streak of religious legitimacy to their sovereignty. Such ritualistic official companionship was a clear physical evidence, in front of the audience, of the tight relationship between the Sultan and the Caliph. Moreover, it was an ostensible clue that the Caliph had willingly chosen the 
new Sultan for this supreme political position. From his turn, the Sultan also aimed at showing his good connection with the Caliph. This trend was not orally expressed, but ostensibly demonstrated by the official sultanic costume of the new sovereign.

The Sultan was dressed in a black Jubbah, while wearing a black turban along with a gilded belt around his waist with a hanging sword. ${ }^{8}$ Black official costumes had always been worn by the 'Abbasid Caliphs. Thus, ostensibly, when the Mamlūk Sultan wore the same official 'Abbasid costume in black, he was demonstrating his loyalty to the Caliph. ${ }^{9}$ However, we believe that such clothing incident does feature a symbolic notion, that is, the Mamlūk Sultan, through using the 'Abbasid caliphal dress code, was signifying himself, indirectly, as the factual sovereign and Islamic leader, while the 'Abbasid Caliph merely turned to be a puppet Caliph. In the same context of colors role and symbolism in the Sultanic procession, "yellow" was a predominant color in the cortege ceremonies, such as the golden belt of the Sultan along with a royal parasol which was held by an Amīr kabïr over the head of the Sultan to protect him from the Sun lamp. That parasol was embroidered in golden threads and was famous for being topped by a gilded figure of a bird. Based on the fact that "yellow" was the predominant color of the Ayyubids, ${ }^{10}$ it could be possibly assumed that the Mamlüks used the same color to convey the public a symbolic message of loyality to the Ayyubids, thus, relatively vindicating themselves from the public accusation of usurping the throne from their former masters.

Obviously, acquiring the public satisfaction with the Sultan's ascension was not the sole objective behind parading; it was also a power demo by Sultan and his cabinet, in front of the public, in terms of delivering an indirect warning to the populace that any political-related rebellions or oppositions would be promptly met by the authorities. This trend is illustrated in the presences of various hierarchies in the procession. For instance, the entire procession was preceded by the commander of the sultanic guards, while the Sultan himself was surrounded by a battalion of personal guards, lancers and ax bearers in anticipation of any potential violence from the populace against the Sultan. ${ }^{11}$

Despite the fact that the sultanic processions were primarily oriented towards propagandizing the Sultan's ascension to the throne, they had also featured many other aspects, all of which could help in achieving a better understanding of the political socio-economic aspects of Mamlūk Egypt. The second reign of Sultan al-Nāșir Muhammad Ibn Qalāwūn (1298-1308) witnessed a blatant interference by Amūrs, Baybars al-Jashānkīr and Salār in al-Nāșir's authority. When al-Nāșir was drastically fed up with the two Amīrs, he plotted against them, but unfortunately the conspiracy was exposed, so the populace, out of their support to al-Nāșir, went revolting across Cairo and they did not calm down until al-Nāșir showed up to them in a venerable sultanic procession which exhibited al-Darb al-Sultani. ${ }^{12}$ Therefore, it could be understood that sultanic processions were sometimes used in pacifying and reassuring the public.

From a different angle, many Mamlūk Sultans were keen on establishing a public solid trust in their political-military abilities. Sultanic victory processions could be taken as good examples to illustrate this orientation. Upon returning back to Cairo after a victorious military campaign, mainly outside Egypt, the Mamlūk Sultan was received by a sultanic procession organized by the state and the populace themselves to glorify and honor the victorious Sultan. The public decorated the selected processional route with handmade maquette of Arc de triumph, whilst the Mamlūk Amīrs executed the same decoration, but with special made citadel maquettes. Before the Sultan's arrival by one day, many people went to rent special spots, overlooking the processional route, for better view. The public paid almost 4 dīnārs for a spot in a house and one dīnār for a spot in a shop. ${ }^{13}$

In most of those sultanic victory parades, the populace, upon receiving the Sultan, raised their holy texts; so it was normal to see the Qur'ān besides the Bible and the Torah. ${ }^{14}$ This specific incident stands as an evidence of the fact that some Mamlūk Sultans were oriented towards religious tolerance. It is noteworthy to mention that displaying captives or war prisoners was in most of the cases, a prime ritual in such political-military processions in connection with materializing and demonstrating the Sultan's power and victory over the state's enemies, a scene the public did not get a chance to see in the battlefield. ${ }^{15}$ In case war captives were present in the procession, they were placed handcuffed at the very front of the cortege to be well seen by the audience, and to show their degenerated banners and their ruptured war drums. ${ }^{16}$ Sultan al-Ashraf Barsbāy had always taken pride in his remarkable military victory over Cypriots in 1426. His famous campaign resulted in subduing Cyprus and capturing its king, Janus, along with thousands of war prisoners all of them were shipped to Cairo to be exposed to the public in Barsbāy's victory parade. ${ }^{17}$ The Cypriot king was enforced to mount a crippled mule while exhibiting the processional route in terms of humiliating his majestic image in front of his defeated army and, of course, the Egyptian populace. ${ }^{18}$

Although the booming economic conditions of the state, especially under the Bahri (1250-1382 AD) and early Burjī periods (1382-1517 AD), had been among the main reasons behind classifying the Mamlūk period as the golden epoch of Egypt's Islamic history, the Egyptian populace, as a margined stratum, rarely enjoyed the financial outcomes of the Mamlūk economy and unfortunately they continued living in tangible poverty. Therefore, they had always been keen of attending most of the Mamlūk's official processions in terms of gaining any sort of financial profit. In their different processions, especially the sultanic, most of the Mamlūk Sultans followed the same protocol of being followed by the cavalry. From one perspective, they protected the back of the Sultan and his entourage, from the other perspective; they were authorized by the Sultan to disperse and sprinkle silver and golden coin, of different values, on the watching community on his behalf. In some cases, the Sultan, by himself, threw the coin to the public, such as al-Ashraf Barsbāy who, in his sultanic procession, disbursed a fortune of silver and golden coins on the populace. ${ }^{19}$ The public, in most Mamlūk processions, were not quite satisfied by what they randomly receive from the Sultan, thus, they exhibited different ways, although sometimes illegal, to maximize their financial benefits from the processions. In many cases, the processional route was covered with pure silk tapestries for the Sultan horse to step on while parading. Certainly, this ritual was executed in respect of demonstrating the Sultan's pomp. For example, when Sultan Qāytbāy returned from his delta tour in 1469 , he wore ceremonial finery and passed through Bāb al-Nașr on a tapestry of yellow silk. ${ }^{20}$ 
Normally after the procession, those fine tapestries were collected by the master of wardrobe, but in many cases, the Sultan ordered that those silk tapestries should be left behind for the public to keep or to sell. ${ }^{21}$ From a different perspective, to fawn the populace, the Mamlūk Sultans carefully looked after preparing food banquets for the public to enjoy as a genuine tradition in many processions. Right after performing the 'id procession and prayer, the Sultan ordered a huge public banquet to be set up for the populace who came specifically to join the Sultan in performing the 'id prayer. This socio-religious tradition featured a mutual benefit between the sultan and his subjects. For the sultan, he demonstrated his piety and generosity, while the public enjoyed eating free food of high quality. ${ }^{22}$

Wafă' al-Nīl procession had always been a prime social occasion in connection with rendering the Sultan visible before his subjects and proclaiming the grandeur of his station. ${ }^{23}$ The ceremony was strictly adhered to the inundation season; it started when the Nilometer, at Rawda Island, recorded a water level of 16 cubits. ${ }^{24}$ This procession was known as mawakib takhlīq al-miqyās "the Nilometer anointing," and Kasr al-Khalīj "cutting the dyke of the Khlīj". ${ }^{25}$ The procession was broadly witnessed by the populace from all over the country for the Sultan generously disbursed money of the watching audience on his way from the citadel to the Nile bank at alFusțāt. Moreover, he continued sprinkling coinage when he was sailing, along with his entourage, on board of the two royal corvettes; al-aqaba and al-Dahabia, to the Nilometer and then to al-Khalij, as the public sailed behind the royal corvettes in their smaller boats to acquire the Sultan's gifts. ${ }^{26}$

Pleasing the public did not, all the way, take the straight materialistic way of disbersing money or preparing banquets. On the contrary, sometimes, the Sultan's moral courtship to the public was as important as his physical courtship. Being quite familiar with this social technique, most of the Mamlūk Sultans exploited the procession ceremonies in socializing and deeply interacting with their subjects through listening, face to face to their complaints or demands, or even to be handed a petition. ${ }^{27}$ Psychologically, the Mamlūk Sultan, through adopting this social ritual, was placing himself in the costume of modesty and concern about the public demands, thus, it was another political tool of pleasing the public to acquire their support.

Certainly, the Mamlūk Sultans had carefully chosen the processional routes within Cairo and its environs in connection with serving their aims of being viewed, while parading, by the maximum number of their subjects in respect of consolidating their power. ${ }^{28}$ Al-Darb al-Sulțānī was the main processional route in Cairo for most of the official corteges, namely, the sultanic, the military, al-Mahmal and the funerary corteges. The beginning of the route was at cairo's citadel, then it extended northwards, through the northern cemetery, till Qubbat alNașr (fig.2) before it deviates westwards towards Bāb al- Nașr in the northern Fatimid enclosure of Cairo. The next phase of al- Darb al-Sulțān̄̄ featured al-Shari` al-A'žam or al-Qașaba southwards till Bāb Zuwayla to exhibit afterwards Shari' al- Darb al-Ahmar then Shari' Bāb al-Wazīr till it ends at the citadel once again. ${ }^{29}$ Therefore, it could be clearly understood that the Sultans meant for their processions to exhibit dense populated areas, especially al-Qașaba which is popularly known as Shari' al-Mu'izz. This historic route truly flourished under the Mamlūks who followed the same path of their former masters i.e. the Ayyubids in exploiting the street as a grand Cairene commercial and residential center. Gradually, the street became flanked on either side by numerous stores and wikālas which traded in both local and imported merchandises. ${ }^{30}$ Accordingly, it turned to be among the healthiest processional environments across Cairo in respect of enabling the Sultan to deliver his symbolic messages to the dense crowds.

Remarkably, the concept of procession did have its impact on the Mamlūk urban development trends. In different words, many of the Mamlūk Sultans were keen on exploiting the areas surrounding the main processional veins, especially in Cairo's outskirts to carry out their urbanization plans in terms of lessening the population density in Cairo through creating new residential and commercial districts. The northern cemetery could be a reasonable example within the urbanization context of Cairo's outskirts. Al-Nāṣir Muhammad Ibn Qalāwūn is credited for starting a revolutionary building program in the cemetery rather than merely exploiting it as a processional area. This urbanization trend was, more or less, followed by many of the Mamlūk Sultans until the end of the Mamlūk period. ${ }^{31}$ The most famous trend towards urbanizing the cemetery was that of al-Nāșir Faraj Ibn Barqūq who prominently based his plan on the adoption of secular architecture in the area. Firstly, he moved the camels market from the maydān under the citadel to that spacious area which preceded his funerary khānqāh, and then he supported his newly established market by a series of service foundations to serve the market clients from different perspectives, such as a bakery, a public bathhouse and a mill. ${ }^{32}$ Unfortunately, the whole project was abandoned after al- Nāșir's assassination in Syria, and the camels market was moved back to its original locality in the maydān.

Will I be remembered? I believe this question had frequently come across the minds of most Mamlūk Sultans. Certainly, they realized that any sort of moral memories could eventually fade; thus, they resorted to various materialistic solutions to commemorate their names, overtime, as pious Sultans and good sovereigns. Those solutions were prominently illustrated in their priceless architectural complexes which flanked the main Cairene processional routes, especially Shari al-Mu'izz ${ }^{33}$ in terms of drawing the attention of the greatest number of people towards memorizing the patrons of those complexes. This sultanic mundane trend was firmly associated to an important religious concept that was acquiring the supplications of the populace for the Sultan after his passing. In this context, the Mamlūk Sultans believed that if their religious charitable complexes, which were basically built to be an ongoing charity, are located at dense populated or visited areas, they would attract huge numbers of people to visit or, at least, to view them. Accordingly, most of the people will, most probably, make a sincere supplication to Allāh to have mercy on the deceased Sultan and his family for their tangible piety and sanctity. Thereupon, it is now clear that the processional itineraries did have an impact on the locality choice of major sultanic religious complexes in Cairo. Indeed, such selective localities exerted some kind of pressure over the Sultan, as a patron, and his architects to carefully adapt the building or the complex to the general conditions which surround the chosen spot, such as the space, the height, the alignment to the processional route and the precise qibla orientation. ${ }^{34}$ For instance, the main façade of al-Manșūr Qalāwūn's funerary complex does 
feature a slight deviation from the street alignment so as to allow the mihrabs to be precisely oriented towards the qibla.

I believe that it was fully intended by the Mamlūk Sultans, as patrons, to place a distinctive, eye catching, architectural or artistic element within their religious complexes, which overlooked a processional route, to prominently draw the attention of the viewer to the whole establishment. Examples, are the humongous mausoleum of Sultan al-Manșūr Qalāwūn (1283-84) whose width exceeds that of the madrasa, (fig.3), ${ }^{36}$ additionally, the striking reused Gothic portal of al-Nāșir Muhammad's madrasa (1295-1303), (fig.4), and above it the most densely decorated minaret across Cairo. ${ }^{37}$ In the same architectural context, I believe it is also useful to underscore the two minarets of the mosque of Sultan al-Mu'ayyad Shaykh (1416-20), which are the most prominently located of all the minarets of Cairo. They stand like a pair of stencils on the twin towers of Bāb Zuwayla, thus, facing the processions entering the heart of the city along its main artery from the south. (fig.5) ${ }^{38}$

In the same context of demonstrating the impact of official Mamlūk parading on the architectural life, it is noteworthy to mention a unique architectural example built specifically by Sultan Qāytbāy, in the northern cemetery, few meters away to the north of his famous funerary complex that is the animal trough. It could be strongly assumed that it was established out of Qāytbāy's piety to provide the animals, used in different processions, by water, in addition to the animals of the regular visitors of the cemetery and those of the Sultan himself. (fig.6) ${ }^{39}$ Above all, the architects of the Mamlūk period succeeded in proving their architectural talents through precisely determining the inclination angle of the facades overlooking al-Darb al-Sultāni and Shari' alMu'izz so as to allow the Mamlūk Sultans, while binging procession, to clearly observe those facades whether the orientation of the street was based on a south-north axis, like in al- Darb al-Sulțānī case (fig.7), or on a northsouth axis as in Shari' al-Mu'izz. (fig. 8 ) $^{40}$

Throughout the Mamlūk period, most of the Sultans had always aimed at demonstrating themselves as leaders of the Islamic world, defenders of Islam against its infidels, and upholders of Sunni orthodoxy madhab. ${ }^{41}$ Evidently, this trend looks like a religious trend in its core, but in many cases, it was merely a religious political device to convince the populace by their significant religious role in terms of acquiring their respect and support. The Procession was an effective cultural device, for the Sultans, in terms of affirming their religious role in the society. The previously mentioned trend could be illustrated in the Sultans' concern about organizing mawkib dawrān al-Mạ̣mal or the Maḥmal procession. Unlike any other procession, the Mahmal was organized twice a year, the first was in the last half of Rajab, and thus, it was commonly known as "al-Mahmal al-Rajabī." procession toured the city of Cairo to display the kiswa of maqqām Ibrāhīm and al-kiswa al-sharīfa of al-Ka'ba which was remarkably woven in pure black silk embroidered in golden threads. ${ }^{43}$

The ceremony started at Bāb al-Nașr before exhibiting Shari' al-Mu'izz on its way to the citadel to be viewed by the Sultan who did not participate in the procession activities within the city, and then the procession ended at al-Fusțāț. ${ }^{44}$ This Mahmal procession enclosed a symbolic message from the Sultan, as the ruler of alHijāz, to his subjects in Egypt and Syria that the pilgrimage route is safe, secured and ready for the early pilgrims to Mecca. ${ }^{45}$ The second Mahmal procession took place in the middle of the month of Shawāl, it exhibited the same processional route of al-Mahmal al-Rajabī, but instead of ending at al- Fustāt, it continued through al- Darb al-Sulțānī to al-Raydāniyah then continued straight to al-Hijāz. ${ }^{46}$ Notably, both processions symbolized the religious role of the Sultan as the guardian of the two holy shrines and the pious defender and protector of Islam in front his subjects. ${ }^{47}$

In some cases the Sultan took advantage of parading to add that proclaimed religious streak to him through making some sort of connection between himself and a highly venerated Islamic figure, especially if mentioned in the Holy Qur'ān. Sultan Qanșūh al- Ghawrī appeared in front of the populace in his processions wearing a unique turban. It was a large turban with an upward pointing double ended knot, which had possibly been a symbolic reference to Dhu'l Qarnayn who was mentioned in Surat al-Kahf, and was popularly associated with Alexander the Great. ${ }^{48}$

It will be quite memorable, overtime, that the Mamlūk's military supremacy, in both battles of al-Mansūra (1250), and 'ain-Jalūt (1260), was the cornerstone in their ascension to the throne and the creation of the Mamlūk dynasty. Naturally, the Mamlūk period had been overshadowed with a notable military spirit from the beginning to the end. Consequently, the Sultans had always been keen on preserving their military rank among other nations, also on continuously developing the military skills of their army in the shadow of their broader eagerness for consolidating their political authority in Egypt and the Levant. Military processions were among the most effective tools by which the Sultans achieved their political-military targets within the sultanate or across its borders. Historically al-Žāhir Baybars was the first Sultan who organized, military parades. ${ }^{49}$ If his army was not in the battlefield, Baybars automatically organized military parades within the citadel and later in maydān al-Qabaq. ${ }^{50}$ Upon departing the citadel with their army, towards maydān al-Qabaq, the Sultans had always organized remarkable military parades which exhibited al- Darb al-Sultānī in terms of demonstrating their power in front of the populace. The scholarship of the Mamlūk military parades and trainings which took place in the different maydāns, especially maydān al-Qabaq, gave us a clear idea about the different sports practiced by the Mamlūks. ${ }^{51}$ For example, the Qabaq game; Qabaq is a Turkish word which could be translated to pumpkin. In this game a mounted bowman aims his arrow towards a silver or golden pumpkin fixed on a high pole in respect of precisely hitting the target. Jūkān was another popular game practiced by the Sultan, his Amīrs and equestrians within the maydān. They used a long stick ending in a goose neck shape to hit a ball. ${ }^{52}$ This sport had commonly been known as Polo sport. Military parading and training within maydān al-Qabaq was, sometimes, regarded as a political event through which the participants from the military caste expressed and renewed their loyalty to the Sultan. For example, after watching a tournament of lancers, Sultan Khushqadam allowed the participants, under the leadership of Qāytbāy, the future Sultan, to step forward to kiss his hand and the floor before him as a sign of loyalty. ${ }^{53}$ It happened, as well, that the Sultan himself had joined the Amìrs and the army in practicing different sports. This was a symbolic message from the Sultan to the participants that he was truly content with everybody. ${ }^{54}$ Sometimes, the Sultan might allow the populace into the maydān to view the 
parading and training activities, and even to participate in different sportive competitions to show the Mamlūk caste their skills. Seemingly, that was a political device adopted by the Sultan to show his modesty and tolerance towards the Egyptian populace. It happened in some cases, that the Sultan would incorporate a social event into a military procession to add a ceremonious streak to that event. In 1293, Sultan al-Ashraf Khalīl launched a pompous military parade, through al- Darb al-Sulțānī, heading towards maydān al-Qabaq in honor of the forthcoming birth of his first son. When the new born was be an unwanted girl, the Sultan claimed, in front of the crowds, that the celebration was originally held to celebrate the circumcision of his younger brother Muhammad and his nephew Muzzafar al-Dīn Musa. ${ }^{55}$ We can learn from this incident that the medieval Egyptian society featured many pre-Islamic, unaccepted, social traditions, especially favoring males over females. As for circumcision, it was a grand social occasion in Mamlūk Egypt. Upon celebrating their son's circumcision, most of the Mamlūk Sultans prepared huge banquets for their Amīrs, army and the populace as well, where precious gifts and coins were distributed among them. ${ }^{56}$

As a matter of fact, many Mamlūk Sultans seized every possible opportunity to demonstrate their pageantry in front of their subjects so as to alleviate the peoples' remembrance and thoughts about their origins as military slaves. Hunting corteges were among their prominent social tools in regards to achieving their aimed social targets. ${ }^{57}$ Hunting had always been regarded by Mamlūk Sultans as an elite sport which helps in disciplining ethics and morals, thus, they showed clear enthusiasm in practicing and learning its skills, especially in the non-war time. ${ }^{58}$ Remote places, especially the deserts were the Sultans' favorite spots for hunting, such as the spacious desert around Giza pyramids. Therefore, many sultanic hunting processions were organized for the Sultan and his entourage, Based on the fact that the Sultans sought behind their hunting trips to enjoy some informality and privacy, they were merely accompanied, in most of their hunting trips, by few of their closest Amīrs and personal guards. Consequently, many of those hunting trips became tragic turning points in the history of Mamlūk Egypt. For instance, on his way back to Egypt, after his memorable victory over the Mongols in 'Ain Jalūt battle (1260), al-Muz̧affar Quțuz was interested in performing a short hunting trip at al-Qusair. He left the main Mamlūk camp with few of his closest trustful Amīrs who showed an interest in sharing the Sultan his hunting activities. Unfortunately, when Quțuz was far enough from his camp, the Amīrs plotted against him and he was brutally assassinated by Baybars. Most historic scholarships affirm that Baybars felt like avenging from Quțuz for the later had participated in the assassination of Baybars master i.e. Fāris al-Dīn Agțāi, also because Quțuz temporized in fulfilling his promise to Baybars to appoint him as the nā'ib of Aleppo. ${ }^{59}$ From a different point of view, as professional tour guides, we could learn from the scholarship of hunting trips and processions few pieces of information about the main animals which were used in those trips. Most of the Sultans were keen on taking certain animals and birds while practicing hunting activities, such as trained leopards, hunting dogs and birds of prey. ${ }^{60}$

Although being different in nature from all previously mentioned processions, analyzing Mamlūk sultanic funerary processions is still remarkably significant in terms of acquainting professional tour guides with the major outlines of the funerary culture and rituals in Mamlūk Egypt. Such mortuary information could be really helpful upon addressing the historic backgrounds of Mamlūk funerary complexes in Cairo. For instance, the

funerary procession of al-Malik al-Sa ‘̄d Muhammad Ibn al-Ẓāhir Baybars which provided us with few important

pieces of information about many of the prevailing mortuary traditions back then. Upon exhibiting the processional route, the khawndāt and their slave girls walked in the funeral with torn clothes while mourning. These traditions are clear evidence that some ancient Egyptian funerary traditions were still prevailing in the Mamlūk period. The Greek historian Herodotus mentioned in his book, the history of Egypt, that when an Egyptian dies the women mourners toured the city or the village streets while, beating their breasts and tearing off their clothes in terms of expressing their grief. ${ }^{61}$

From a different perspective, the medieval Egyptian society perceived the passing of a funeral within the city's walls with excessive pessimism. ${ }^{62}$ For instance, when Sultan Abu-Sa'Td Jaqmaq's son Muhammad died in 1450 , his funerary procession passed through Bāb Zuwayla heading northwards towards al-Barqūqiya where his body was interred. The passing of the funeral within Cairo resulted in a tangible pessimism among the Cairene populace. ${ }^{63}$ Accordingly, most of later funerary processions, which aimed the heart of Cairo, exhibited side streets and allies to avoid passing through one of the main gates of Cairo. For example, when the majestic funerary procession of Muhammad, son of Sultan al-Ghawrī, departed the citadel, it aimed al-Darb al-Ahmar area where it passed through "Khukhit Aydukmish" till Ḥārit al-Rūm, to end at Qubbat al-Ghawrī, on Shari" alMu'izz, where the body was interred. This whole alternative plan was executed specifically to avoid passing through Bāb-Zuwayla with the casket. ${ }^{64}$ It is noted that the official mourning clothes were white in color, a theme which was inherited from the Ayyubids. ${ }^{65}$ Generally speaking, colors played an important role in distinguishing between the various religious and social strata of the populace who viewed any of the previously mentioned processions. For example, the green color was exclusively reserved for al-Ashrāf or the descendants of the prophet Muhammad (PBUH) in terms of honoring this stratum, ${ }^{66}$ while the Christians were distinguished through their blue turbans. ${ }^{67}$

From a different perspective, the scholarship of Mamlūk religious processions allowed us to be enlightened with many of the medieval social traditions and the popular culture of celebration. On the days of great processions, notably on the occasion of al-Mahmal and pilgrimage processions, gender segregation was forgone in the decorated city, where crowds of men and women gathered. Women would sit on vendor's benches and even sometimes spend the night in a shop in order not to miss the spectacle next morning. Such behavior was sometimes condemned as promoting promiscuity. ${ }^{68}$ Despite the religious spirit which overshadowed the Mahmal processions, it was sometimes a time of wrong doings, especially by that group which was known as 
'Afārīt al-Mamālīk. This group took advantage of the crowdedness, during the procession, and extremely bothered the people through stealing their personal belongings and money, especially men's turbans. Their awkward behavior had sometimes crossed the limits to even kidnapping boys and women. ${ }^{69}$ Also, we learned that during the celebration of various processions, many Mamlūk Sultans ordered the installment of sweet lemon juice troughs in many spots along the processional routes for the people to drink and enjoy. ${ }^{70}$

Finally, throughout the Mamlūk period, there were unique processions which were organized only once as a reflection of certain circumstances. In this context, it is interesting to know that Qāytbāy organized a grand procession in 1471 to celebrate his recovery from his leg fracture. The Sultan's capacity to ride a horse after such on injury at his age symbolized his restored competence as a war leader in front the populace. ${ }^{71}$ In some cases, a Mamlūk Sultan would add an unusual touch of pageantry to any of his processions to draw the attention of the populace. For example, Sultan al-Ghawrī used a group of elephants to precede his mahmal and military processions; they carried the Mamlūk banners and were surrounded by a group of drummers to be more attractive.

\section{Conclusion}

In conclusion, official procession, throughout the Mamlūk dynasty, had been one of the most effective cultural tools to consolidate their political authority and their socio- religious and military roles within the Egyptian society. Such required consolidation had been relatively achieved, to a great extent, through conveying many different physical and symbolic messages to the public throughout the different activities of the previously mentioned processions. Furthermore, Mamlūk processions, regardless of their nature, proved and established themselves to be substantial sources of historical information in connection with different life aspects of medieval Egypt, especially from the religious, social, economic and architectural perspectives. Such analyzed historic input is highly advised to be used by professional tour guides upon identifying the philosophical background of the visited Mamlūk historic site. Ultimately, We strongly believe that any tour guide, especially in the field of Islamic archaeology-related tourism, should always be academically trained, through specialized tour guiding short courses, to properly use a sharp analytic eye while studying any historical theme, such as the different aspects of Mamlūk processions, for such investigative eye will always help in revealing more information about this period which has always been proving its worthiness to be entitled as the golden epoch of Egypt's Islamic history.

\section{Bibliography}

Doris Behrens-Abouseif: The minarets of Cairo, (American University in Cairo Press Cairo, 1985).

Doris Behrens-Abouseif, Cairo of the Mamluks: A History of Architecture and its culture (The American University in Cairo Press, Cairo, 2007).

'Ināyāt Muḥammad Aḥmad, Tarīkh Mașr fi al-'Asrayn al-Yunān̄̄ wal-Romānī (MaktabPharos,Alexandria, 2005). Muhạmmad ibn Ahmad ibn Iyās al-Hạafī, Badā'i al-zuhūr fĩ waqū'i al-duhūr (Frānz Shtāynar, Fīsbādin, 1972).

Muhạmmad ibn 'Abd al-Rahṃān al-Sakhāwī ; murāia'at Sa'īd 'Abd al-Fattāh 'Āshūr ; tahqīq Najwá Musțạá Kāmil, Labībah Ibrāhīm Mustafá.Kitāb, al-Tibr al-masbūk fì dhayl al-sulūk (Matbạa'at Dār al-Kutub wa-alWathā'iq al-Qawmīyah, Markaz Tahqīq al-Turāth,Cairo, 2002).

'Alī 'Ațiyah et.al, "Al-Mawkib al-Sulțānı̄” in Museum with no Frontiers (al-Dār al-Mișriya al-Libanāniya, Cairo, 2007).

Taqiy al-Dīn Ahṃad ibn 'Alī ibn 'Abd al-Qādir ibn Muhammad al-ma'rūf bi-al-Maqrīzī ; 「taqdīm] Muhạmmad Mustafá Zivādah. Khitat al-Maqrīzī al-Mawā'iz wa-al-i'tibār fì dhikr al-khitạt wa-al-āthār (Dār al-Tahrīr lil-tạb“ wa-al-Nashr,Cairo, 1967-1968).

Sa'T̃d 'Abd al-Fattāḥ 'Āshūr, al-Mujtama' al-Mișrī fi 'așr Salātīn al-Mamāt̄̌k (Dār al- Nahdạh al-'Arabīyah, Cairo, 1962).

Sa'̄̃ 'Abd al-Fattāh 'Āshūr, al-'Asr al-Mamālīkī fì Misr wa-al-Shām .(Dār al-Nahdạh al-'Arabīyah, Cairo. 1965). Patricia L. Baker, Islamic textiles (British Museum Press, London, 1995)

Jamāl al-Dīn Ab̄̄ al-Mahā̄sin Yūsuf Ibn Taghrī birdī, al-Nuī̄m al-zāhirah fì mulūk Misr wa-al-Oāhirah (alMu'assasah al-Mistrīyah al-'Ammah lil-Ta'līf wa-al-Tarjamh wa-al-Tịbā'ah wa-al-Nashr,Cairo, 1963-1971).

Muștafá 'Alī Ibrāhīm Duwaydār, Jazīrat al-Rawḍah: mundhu al-fatḥ al-Islāmī hattá nihāyat hukm al-Mamālīk, 20-923 H/640-1517 M (Dār al-Wafā' li-Dunyā al-Ṭibā'ah wa-al-Nashr,Alexandria, 2011).

Hani Hamza, the Northern Cemetery of Cairo (The American University in Cairo Press, Cairo, 2001).

Sumayyah Hạsan Muhạmmad Ibrāhīm, al-'Ādāt al-Misrīyah al-qadīmah fì al-'as! al-Islāmī (Maktabat Gharīb, Cairo, 1989).

Muhammad Ḥussām al-Dīn 'Ismā'̄il, al-'Ușūl al-Mamlūkia Lil'Amā̉ir al-'Uthmāniya (Dār al-Wafă' Li Doniā alTibā'a Wal Nashr, Alexandria, 2002).

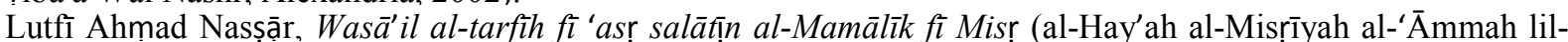
Kitāb, Far' al-Sihāafah, Cairo, 1999).

Bernard O'Kane, the Mosques of Egvpt (The American University in Cairo Press, Cairo, 2016).

Carl F. Petry, Protectors or praetorians? the last Mamlūk sultans and Egypt's waning as a great power (State University of New York Press, Albany, 1994).

Qāsim 'Abduh Qāsim, 'Assr salāțīn al-Mamālīk: al-tārīkh al-siyāsī wa-al-ijtimā'ì (Ayn lil-Dirāsāt wa-al-Buhūth al-Insānīyah wa-al-Ijtimā'īyah, Cairo, 1998).

Caroline Williams, Islamic Monuments in Cairo: the Practical Guide (The American University in Cairo Press, Cairo, 2008)

Philipp Von Zabern, the Egyptian Museum, (Organization of Egyptian Antiquities, Cairo, 1987). 
روئة جديدة فى دراسة المواكب المملوكية الرسمية بمدينة القاهرة و ضواحيها من منظور الإرشاد السياحي: دراسة تحليلية

$$
\text { أحمد عواد حسين }
$$

تُعد المواكب المملوكية الرسمية والتي كثيرا ما جالت بمدينة القاهرة وضواحيها القريبة من أهم الأدوات والوسائل

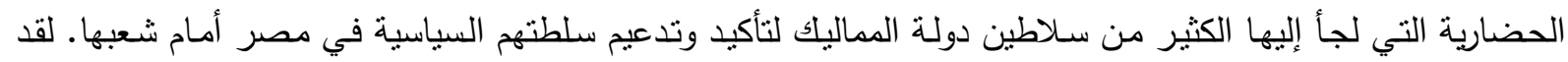

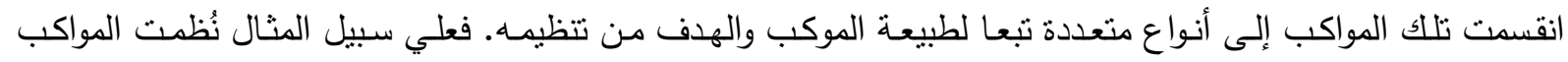

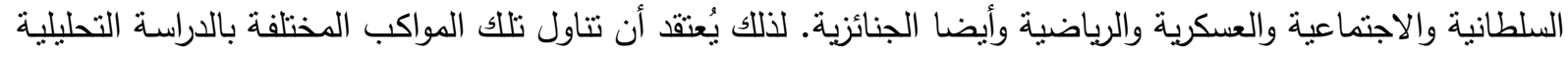

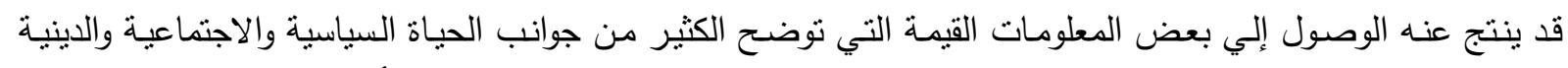

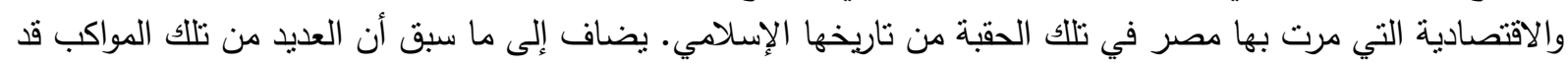

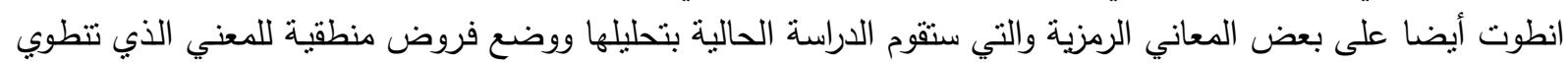

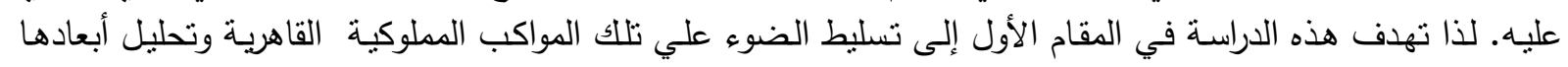

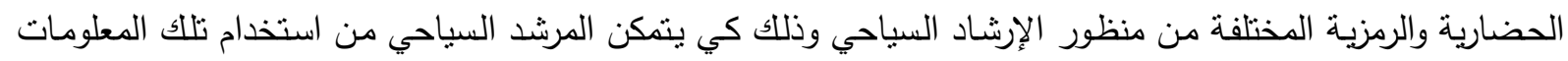

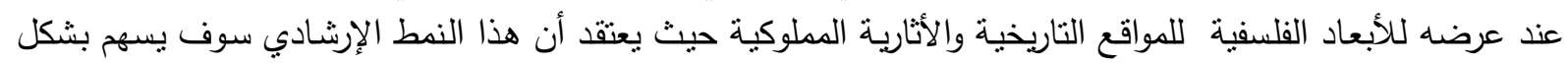

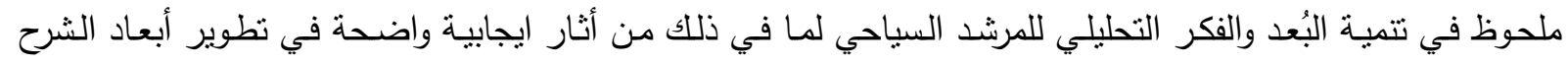
والإرشاد للمجموعات السياحية. 


\section{Figures*}

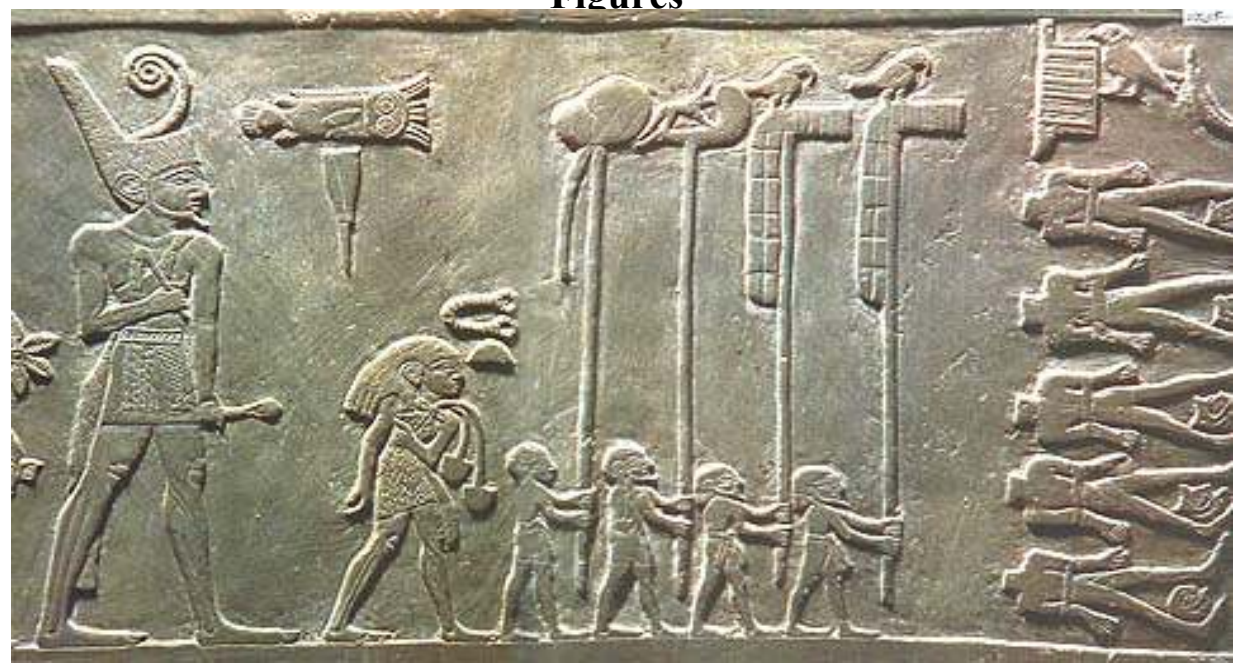

Fig. (1)

Narmer palette

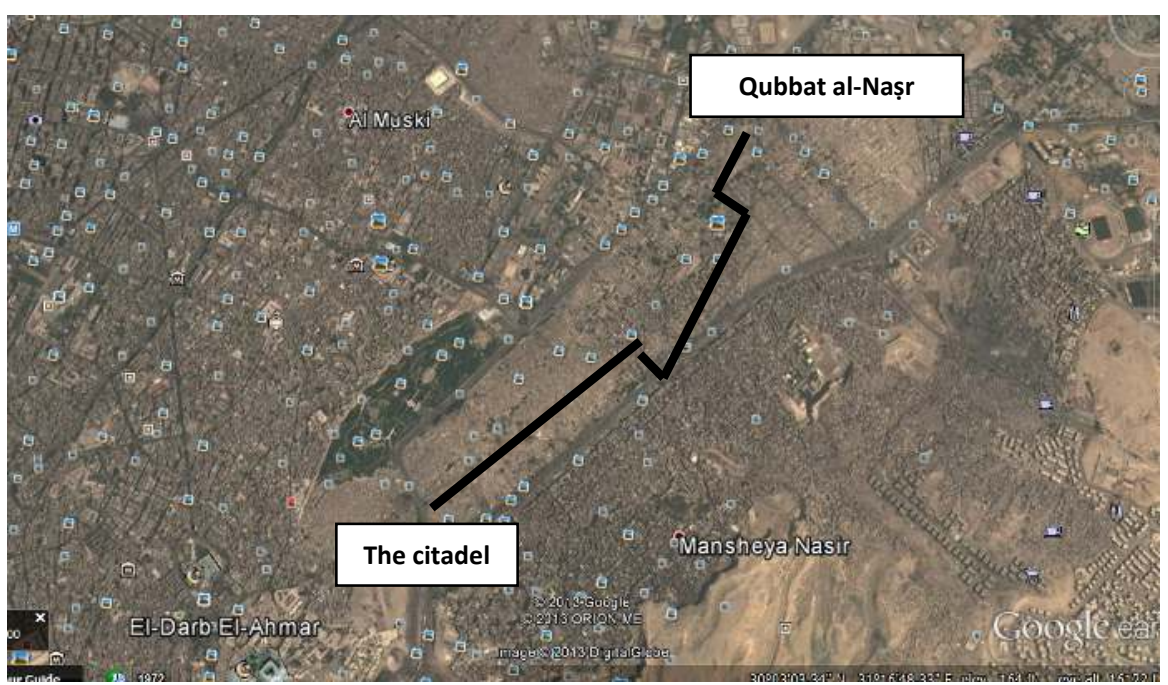

Fig. (2)

The path of al-Darb al-Sulțānī

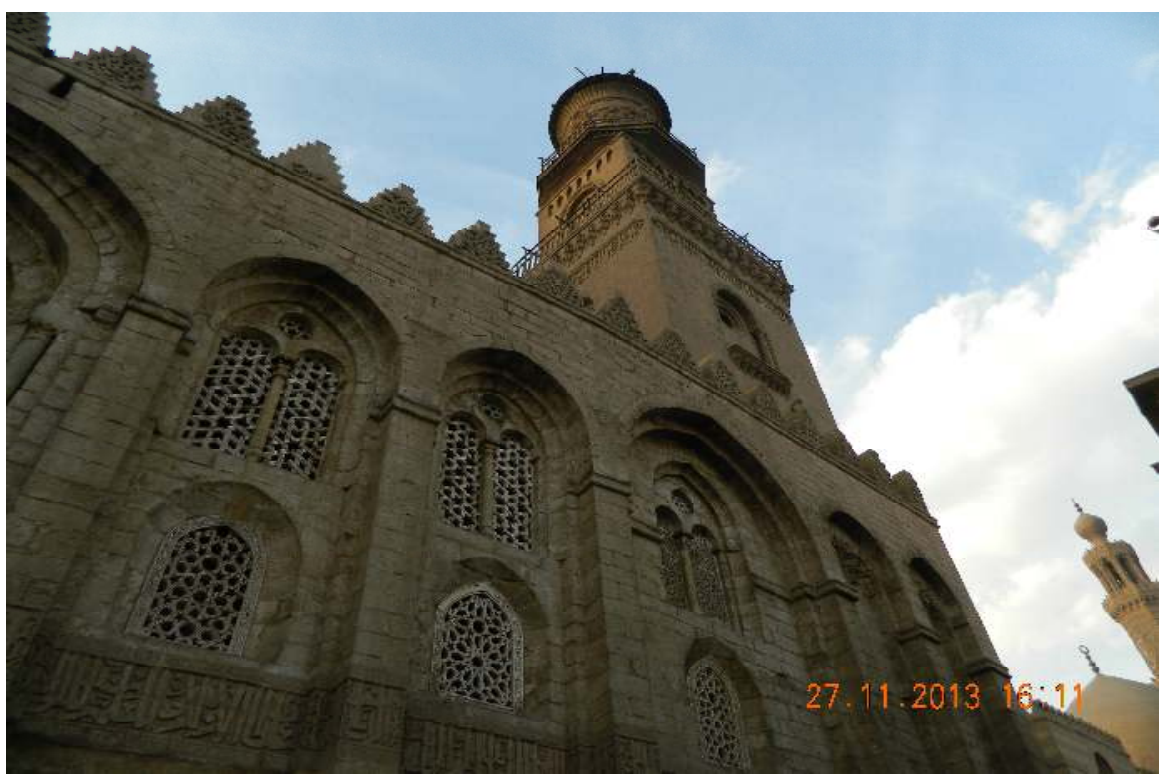


A New Approach to Mamluk Official Processions within Cairo and its Environs from Tour Guiding Perspective An Analytic Study

Fig. (3)

The mausoleum of al-Manșūr Qalāwūn

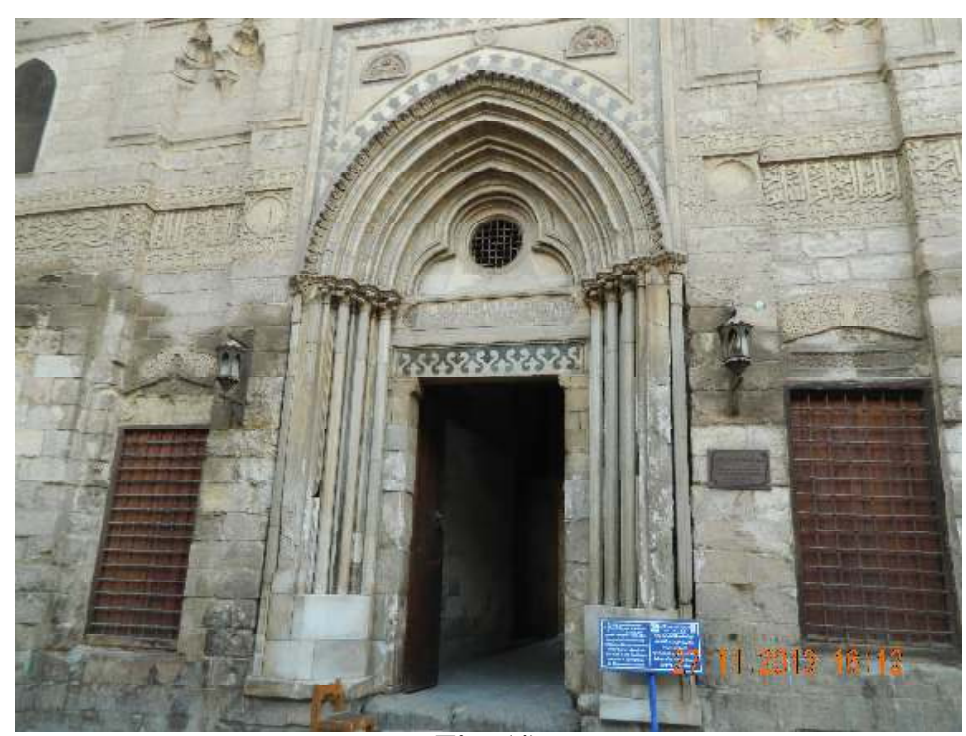

Fig. (4)

The Gothic portal of al-Nāsir Muhammad madrasa

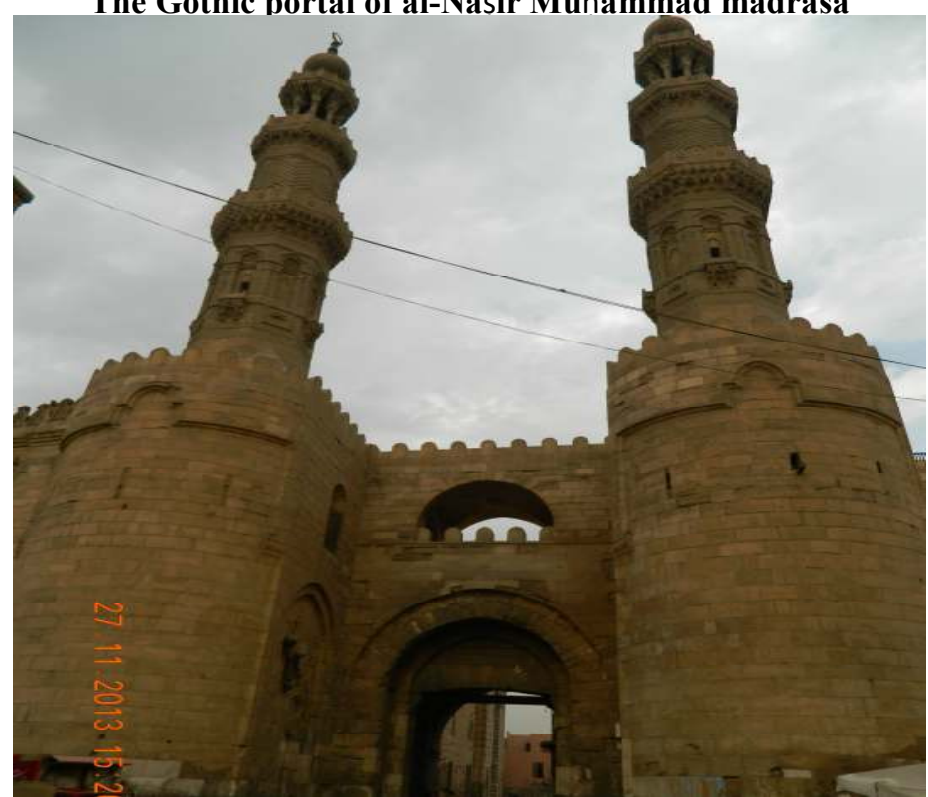

Fig. (5)

The minarets of al-Mu'ayyad Shaykh mosque

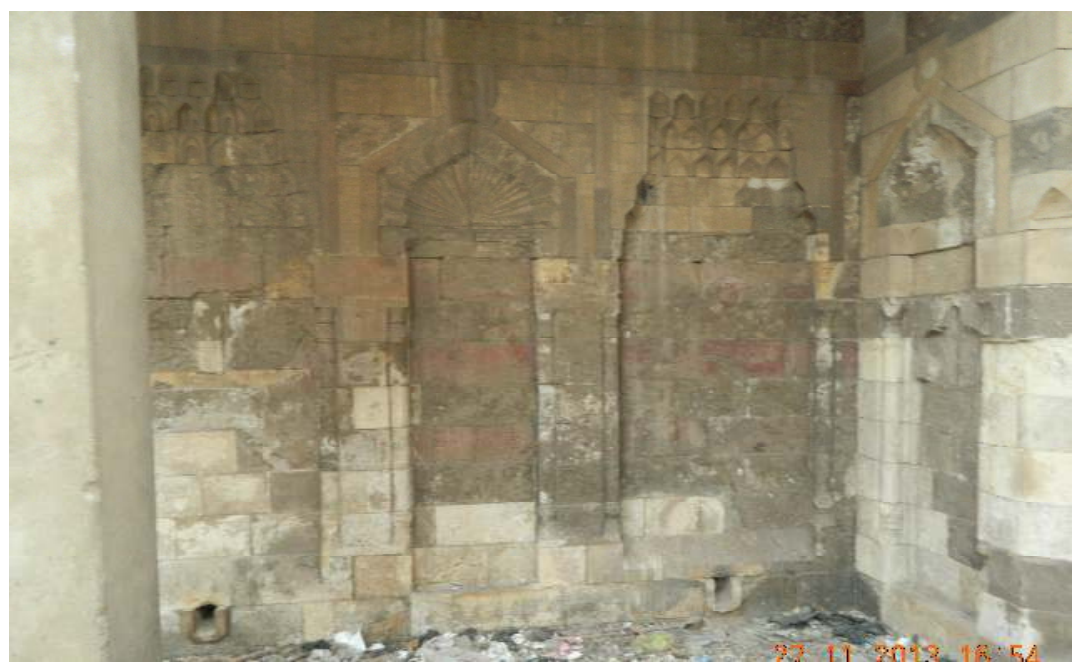


Fig. (6)

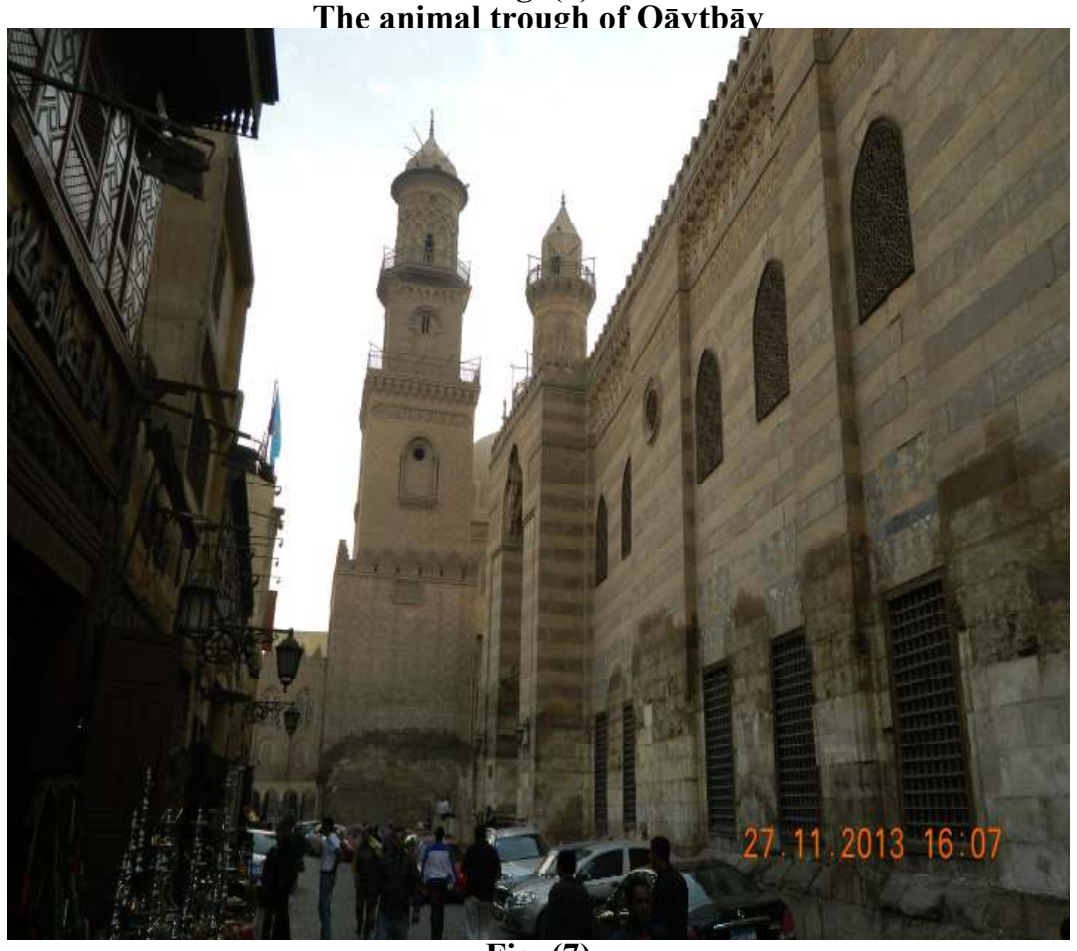

Fig. (7)

Shari' al-Mu izz

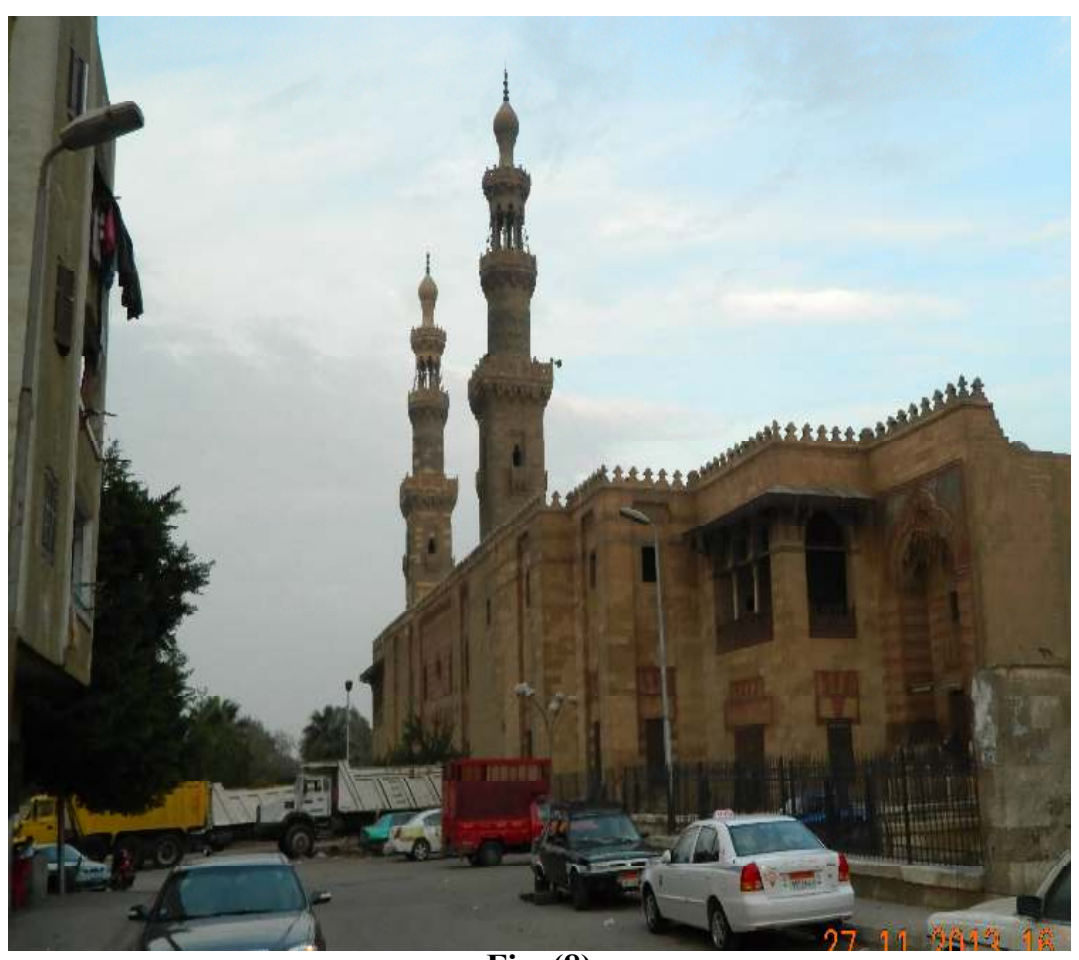

Fig. (8)

Al-Darb al-Sulțānī 


\section{End Not:}

1- Von Zabern, Philipp (1987), The Egyptian Museum, Cairo, Organization of Egyptian Antiquities, pp. 43-44.

2- Muãammad Aḥmad, 'Ināyāt (2005), Tarīkh Maṣr fi al-'Așrayn al-Yunān̄̄ wal- Romānī, Alexandria,

Pharos, p. 157

3- 'Abd al-Fattāḥ 'Āshūr, Sa'̄d (1965), al-'Asṛ al-Mamālīkī fì Miṣ wa-al-Shām, Cairo, Dār al-Nahdạh al'Arabīyah, pp. 336, 337

4- 'Ațiyah, 'Alī et.al (2007), “Al-Mawkib al-Sulțān̄̄” in Museum with no Frontiers, Cairo, al-Dār al-Mișriya al-Libanāniya, p. 96

5- 'Āshūr, Sa'ĩd 'Abd al-Fattāḥ (1962), al-Mujtama' al-Mișrī fi 'aṣr Salātīn al-Mamā̄̄k, Cairo, Dār al- Nahdạh al-'Arabīyah, p. 193

6- Loc.cit; 'Atiyah, al-Mawkib, p. 96

7- Abouseif, Doris (2007), Cairo of the Mamluks: A History of Architecture and its culture, Cairo, The American University in Cairo Press, p. 25

8- Baker, Patricia L. (1995), Islamic textiles, London, British Museum Press, p. 66; 'Atiyah, al-Mawkib, pp. 90,96

9- 'Atiyah, al-Mawkib, p. 90

10- Abouseif, Cairo, p. 26; Baker, Textiles, p. 66

11- 'Aț̄ya, al-Mawkib, p. 96

12- Ibn Taghrī birdī, Jamāl al-Dīn Ab̄̄ al-Mahạ̄sin Yūsuf (1963-1971), al-Nuiūm al-zāhirah fì mulūk Mișr waal-Oāhirah, Cairo, al-Mu'assasah al-Mistrīyah al-'Ammah lil-Ta'līf wa-al-Tariamh wa-al-Tịbā'ah wa-alNashr, pt.8, pp. 173-174; al-Maqrīzī, Taqiy al-Dīn Ahṃad ibn 'Alī ibn 'Abd al-Qādir ibn Muhạmmad (1967-1968), Cairo, Khitạt al-Maqrīzī, al-Mawā'iz wa-al-i'tibār fì dhikr al-khitạt wa-al-āthār Dār al-Tahṛīr lil-tạb' wa-al-Nashr, p. 389

13- 'Āshūr, al-Mujtama', p. 196; Abouseif, Cairo, p. 29

14- 'Āshūr, al-Mujtama', p. 197

15- Abouseif, Cairo, p. 29

16 - 'Āshūr, al-Mujtama', p. 197

17- 'Āshūr, al-'Așr, p. 168

18- Loc. cit.

19- 'Ațīya, al-Mawkib, p. 96

20- Abouseif, Cairo, p. 28

21- Petry, Carl F. (1994), Protectors or praetorians? : the last Mamlūk sultans and Egypt's waning as a great power, Albany, State University of New York Press, p. 158

22- 'Ațīya, al-Mawkib, p. 96; Abouseif, Cairo, p. 28

23- 'Ațiya, al-Mawkib, p. 98

24- Petry, Protectors, p. 158

25- Ibrāhīm, Sumayyah Hạsan Muhạmmad (1989), al-'Ādāt al-Mișīyah al-qadīmah fì al-'asr al-Islāmī, Cairo, Maktabat Gharīb, p.26; Qāsim, 'Abduh Qāsim (1998), 'Assr salātīn al-Mamālīk : al-tārīkh al-siyāsī wa-alijtimā' $\bar{l}$, Cairo, Ayn lil-Dirāsāt wa-al-Buhūth al-Insānīyah wa-al-Ijtimā'̄iyah, p. 303

26- 'Āshūr, al-'Așr, p. 323

27- Duwaydār, Muștafá 'Alī Ibrāhīm (2011), Jazīrat al-Rawḍah : mundhu al-fath al-Islāmī hattá nihāyat hukm al-Mamālīk, 20-923 H/640-1517 M, Alexandria, Dār al-Wafā' li-Dunyā al-Ṭibā'ah wa-al-Nashr, p. 529, 532; 'Ațīya, al-Mawkib, p. 152

28- 'Ismā̄îl, Muḥammad Ḥussām al-Dīn (2002), al-'Ușūl al-Mamlūkia Lil'Amā 'ir al-'Uthmāniya, Alexandria, Dār al-Wafă' Li Doniā al-Ṭibā'a Wal Nashrp, p. 16

29- Birdī, al-Nujūm, pt. 1, p. 7, 41; 'Āshūr, al-Mujtama', p. 194

30- 'Ațīya, al-Mawkib, p. 172

31- Al-Maqrīzī, al-Khițat, pt. 3, p. 183; Birdī, al-Nuiūm, pt. 9, pp. 168- 169

32- Hamza, Hani (2001), the Northern Cemetery of Cairo, Cairo, The American University in Cairo Press, p. 25

33- 'Ismā '̂̀l, al-'Ușūl, p. 16

34- Al-Kaḥlāwī, al-Qibla, p. 80

35- Loc. cit.

36- Abouseif, Cairo, p. 135.

37- O'Kane. Bernard (2016) the Mosques of Egvpt. Cairo. The American University in Cairo Press, p. 67

38- Abouseif, Doris Behrens (1985), The minarets of Cairo, Cairo, The American University in Cairo Press, $p$. 210

39- Williams, Caroline (2008), Islamic Monuments in Cairo: the Practical Guide, Cairo, The American University in Cairo Press, p. 244

40- 'Ismā'̄il, al-'Ușūl, p. 25

41 - 'Āshūr, al-Mujtama', p. 181; Qāsim, 'Assr, p. 296

42 - 'Āshūr, al-Mujtama', p. 181; Qāsim, 'Așr, p. 296 
43- Nasșạ̄r, Lutf̣ì Ahṃad, (1999), Wasā'il al-tarfìh fì 'aș salātịn al-Mamālīk fì Misṛ, Cairo, al-Hay'ah alMisrīyah al-'Āmmah lil-Kitāb, Far' al-Sihạ̄fah, p. 196; Baker, textiles, p. 66

44- 'Āshūr, al-Mujtama', pp. 181-182; Qāsim, 'Așr, pp. 296- 297

45- 'Ațīya, al-Mawkib, p. 97

46- 'Āshūr, al-Mujtama', p. 190; Āshūr, al-'Așr, pp. 321-322

47- Abouseif, Cairo, p. 31; Nasṣạ̄r, Wasā'il, p. 196; Qāsim, 'Aṣr, p. 296

48- Abouseif, Cairo, p. 26

49- Hamza, Cemetery, p. 2

50- Loc. cit.

51 - 'Āshūr, al-Mujtama', pp. 69, 72

52- Nasșạ̄r, Wasă'il, p. 248; 'Ațīya, al-Mawkib, p. 93

53- Abouseif, Cairo, pp. 25-26

54- Nasșạ̄r, Wasă'il, p .248

55- Hamza, Cemetery, p. 3

56- Ibrāhīm, al-'̄'Āāt, pp. 36-37

57- 'Ațīya, al-Mawkib, p. 6

58- Nasșạar, Wasä'il, p. 212

59- 'Āshūr, al-'Așr, p. 39; Qāsim, 'Așr, p. 76 ; Nasșạ̄r, Wasă'il, p. 214

60- Nasșạ̄r, Wasä'il, p. 223

61- Ibrāhīm, al-'Ādāt, pp. 55, 57

62- Al-Sakhāwī, Muhạmmad ibn 'Abd al-Rahṃān (2002), al-Tibr al-masbūk fì dhayl al-sulūk, Cairo, Matḅa'at Dār al-Kutub wa-al-Wathā'iq al-Qawmīyah, Markaz Tahqīq al-Turāth, p. 337.

63- Ins nit

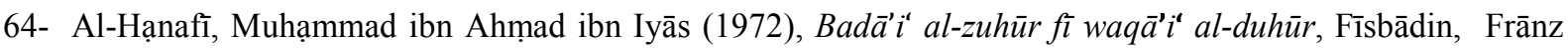

Shtāynar, pt. 4, p. 78

65- Abouseif, Cairo, p. 26

66- Baker, textiles, p. 68

67- Loc. cit.

68- Abouseif, Cairo, p. 29

69- 'Āshūr, al-Mujtama', p. 183

70- 'Āshūr, al-Mujtama', p. 197

71- Petry, Protectors, p. 159

72- Abouseif, Cairo, p. 31; Nasṣạ̄r, Wasā'il, p. 198

* Photographs by the author 